Journal of Agricultural Sciences
(Tarim Bilimleri Dergisi)

\title{
Agronomic Performance of the Alternative Cereal Species in the Highest Plain of \\ Turkey
}

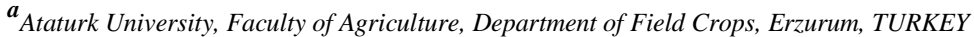

Ali ÖZTÜRK ${ }^{a^{*}} \mathbb{D}$, Sevnur AKKUŞ EKINNCİa ${ }^{\mathbb{D}}$, Selçuk KODAZ ${ }^{\mathbb{D}}$, Murat AYDIN ${ }^{\mathrm{b}}$ (iD)

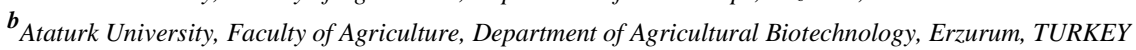

\section{ARTICLE INFO}

Research Article

Corresponding Author: Ali ÖZTÜRK, E-mail: aozturk@atauni.edu.tr

Received: 07 December 2019 / Revised: 02 January 2020 / Accepted: 03 February 2020 / Online: 31 May 2021

\section{ABSTRACT}

Due to their important nutrition and health potential, the interest in einkorn (Triticum monococcum L.) and emmer (Triticum dicoccum Schrank) wheat, as well as naked barley (Hordeum vulgare L. var. nudum) species is increasing. The study examined the agricultural properties related to three einkorn wheats, three emmer wheats and two naked barleys, one bread wheat and one hulled barley in spring sowing under irrigated and rain-fed conditions. Depending on irrigated and rainfed agriculture conditions, the vegetative period of genotypes varied between 59.3-71.7 and 58.2-71.0 days, grain filling period varied between 29.8-38.0 and 26.7-33.8 days, plant height varied between 79.6-105.2 and 79.1-99.0 cm, the number of spike per square-meter varied between 533.3-682.5 and 457.5-573.3, the number of grains per spike varied between 16.1-22.6 and 13.6-20.0, the 1000-kernel weight varied between $31.2-54.6 \mathrm{~g}$ and $28.0-47.6 \mathrm{~g}$, the grain yield varied between $2410-4099 \mathrm{~kg}$ $\mathrm{ha}^{-1}$ and $1716-2660 \mathrm{~kg} \mathrm{ha}^{-1}$, and the crude protein content varied between
$10.1-13.5 \%$ and $10.4-14.8 \%$, respectively. The highest grain yield was obtained from Tokak 157/37 barley cultivar, while the highest crude protein contents were obtained from einkorn genotypes. The number of spike per square-meter, the number of grains per spike, the 1000 kernel weight and the grain yield decreased by $14.6 \%, 9.4 \%, 8.7 \%$, and $26.2 \%$ respectively, while the crude protein content increased by $8.2 \%$ under rain-fed agriculture conditions. It was determined that Özen and Yalın barley varieties could not be an alternative to Tokak 157/37 barley cultivar due to low grain yield and protein content. Einkorn cv. Çatalyazı and emmer wheat cv. Çağlayan in irrigated conditions, and all the einkorn and emmer genotypes in rain-fed conditions were superior to Kırik wheat genotype in terms of grain yield. The genotypes of the einkorn had a significantly higher grain protein content compared to the Kirik and emmer genotypes. It is possible to note that Çatalyazı and Çağlayan genotypes are promising cereals in Erzurum region.

Keywords: Einkorn, Emmer, Naked barley, Yield, Protein

(C) Ankara University, Faculty of Agriculture

\section{Introduction}

The first culture forms and local populations of wheat and barley are important as a genetic source for the improvement of these species (Zaharieva \& Monneveux 2014) and for breeding quality (Lachman et al. 2012 a, b; Longin \& Würschum 2016) and resistance to stress factors (Jaradat 2011; Aslan et al. 2016 a, b) in modern varieties. Einkorn (Triticum monococcum L.) and emmer (Triticum dicoccum Schrank) hulled wheat species, the first plants that were cultured by humankind, are still cultivated in some countries such as Turkey, the Balkans, Italy, France, Spain, Germany, Switzerland and Austria today (Konvalina et al. 2013). Einkorn populations in Kastamonu, Karabük, Samsun and Bilecik provinces of Turkey have been cultivated, while emmer populations in Kars, Ardahan and Kayseri have generally been produced in high altitude and barren-unproductive areas. They are mainly utilized for cracked wheat, bread, pasta, noodles, tarhana soup and animal feed.

Archaeological findings indicate that hulled wheat species, which have different names such as siyez, kabılca, kavilca, gacer, have grown in Turkey for over 10,000 years. Sowing areas of einkorn and emmer wheat species that cannot compete with modern varieties in yield and gains are gradually decreasing. Statistical data demonstrated that hulled wheat producing area in Turkey was 137,000 ha in 1953, while it was 38,000 ha in 1983 and 3076 ha in 2017. Morgounov et al. (2016) reported that the decrease of genetic diversity of the local wheat population in Turkey ranged from 50\% to 70\% compared to 1920 and the main reason why local populations are still grown in limited areas is high grain quality and resistance to abiotic stress factors. Einkorn and emmer wheat, also known as ancient wheat species, have been the subject of numerous studies in recent years. These wheats are defined as functional foods with significant potential for human nutrition and health because of their high protein, fiber, mineral, antioxidant and carotenoid values (Borghi et al. 1996; Brandolini et al. 2008; Chatzav et al. 2010; Lachman et al. 2012 a, b). Moreover, these are recommended as alternative crops for low input agriculture and organic farming conditions due to their resistance to some fungal diseases and pests (Konvalina et al. 2010; Zaharieva \& Monneveux 2014) and their adaptation to poor nutrient soils (Troccoli \& Codianni 2005; Konvalina et al. 2012). Aslan et al. (2016 a) reported that einkorn wheat populations 
were more tolerant of cold stress than bread wheat cultivars during germination period while Feng et al. (2018) pointed out that emmer wheat was a potential gene source in salt stress breeding.

The non-adherent husk status of naked barley is a trait that occurs as a result of mutation after cultivation of the barley and is controlled by a recessive single gene locus (nud) (Taketa et al. 2004). Naked barley is the most common culture in the world in China's Tibetan Plateau and Australia, Mexico, Canada, Japan, Syria and the UK are listed as other producer countries (Zeng 2015). The development of naked barley (Hordeum vulgare L. var. nudum) varieties increases the use of barley in human nutrition with its addition different proportions to bread, pasta and noodles and in the form of soup, porridge, cookies and beverages (Altan et al. 2006; Köten et al. 2013). The interest in naked barley that is a rich source of essential vitamins, minerals and beta-glucan soluble fiber has increased as it is highly recommended as a suitable nutritional option for people with diabetes and cholesterol problems (Kinner et al. 2011; Yan et al. 2016; Sterna et al. 2017).

Although there is an increasing interest in einkorn and emmer wheat as well as naked barley, which have significant potential in terms of nutrition and health, the data on the adaptation of these species to different environmental conditions is limited. Einkorn and emmer populations, which have significant potential for low input agriculture and organic farming are likely to be easily accepted by farmers in the Erzurum region due to their resistance to some diseases and pests and their ability to adapt to poor soils. Three einkorn populations, three emmer populations and two naked barley cultivars, Kurik bread wheat and Tokak 157/37 barley cultivars were tested under Erzurum irrigated and rain-fed agricultural conditions, and some agricultural characteristics and their potential to be alternative products were investigated in this study.

\section{Material and Methods}

This study was carried out during 2017 and 2018 at Ataturk University Plant Production Application and Research Centre in Erzurum (latitude $39^{\circ} 55^{\prime} \mathrm{N}$, longitude $41^{\circ} 61^{\prime} \mathrm{E}, 1853 \mathrm{~m}$ above sea level), Turkey. The experimental material consisted of 10 cereal genotypes, belonging to different species and including local landraces and the modern varieties, were used in this study (Table 1). In the region, the most common varieties of Kirik and Tokak 157/37 were used as checks. The seeds of landraces were sampled in-place from farmers' current crop year harvest stocks. During the vegetation period, the total rainfall was 138.4 and $285.6 \mathrm{~mm}$, the average temperature was 14.9 and $14.6^{\circ} \mathrm{C}$ in 2017 and 2018 , respectively (Table 2). The experimental soil was a clay-loam with $\mathrm{pH}$ of 7.65-7.81, organic matter content $1.51-1.52 \%$, and total $\mathrm{N}$ content $0.088-0.091$. Available $\mathrm{P}$ and $\mathrm{K}$ contents of the soils were 79.2-83.3 and 1237-1267 $\mathrm{kg} \mathrm{ha}^{-1}$, respectively. The experiments were sown on $21^{\text {th }}$ April, 2017 and $20^{\text {th }}$ April 2018 in spring. The experimental design was a randomized complete block in a split-plot configuration with three replications. Main plots were irrigated and rain-fed treatments and subplots were the genotypes. In irrigated treatment, plots were irrigated at booting stage and milk stage of plants. In rain-fed treatment, plants were grown under natural conditions. Plots were sown with a planter. The seeding rate in the experiments for all the genotypes was 500 viable seeds per $\mathrm{m}^{-2}$. Subplots consisted of six plant rows spaced $20 \mathrm{~cm}$ apart, with a row length of $6.0 \mathrm{~m} . \mathrm{N}$ as ammonium sulphate was applied to the plots of $60 \mathrm{~kg}$ ha ${ }^{-1}$ and $\mathrm{P}$ as TSP to the plots of $50 \mathrm{~kg} \mathrm{ha}^{-1}$. Half of $\mathrm{N}$ and all $\mathrm{P}$ were applied at sowing; the second half of $\mathrm{N}$ was applied at the beginning of stem elongation. Weeds were controlled by hand.

Table 1- Names and some traits of the alternative cereal species included in the field experiments

\begin{tabular}{|c|c|c|c|}
\hline & Genotypes & Origin & Some traits \\
\hline \multirow{3}{*}{ 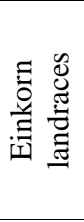 } & Çatalyazı & $\begin{array}{l}\text { Kastamonu } \\
\text { İhsangazi - Catalyazı Village }\end{array}$ & Light brown spike, awny, amber grain \\
\hline & Enbiya & $\begin{array}{l}\text { Kastamonu } \\
\text { İhsangazi - Enbiya Village }\end{array}$ & Yellow spike, awny, amber grain \\
\hline & Musasofular & $\begin{array}{l}\text { Bolu } \\
\text { Seben - Musasofular Village }\end{array}$ & White spike, awny, amber grain \\
\hline \multirow{3}{*}{ 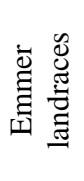 } & Yildırımtepe & $\begin{array}{l}\text { Ardahan } \\
\text { Çıldır - Yıldırımtepe Village }\end{array}$ & Brown spike, awny, amber grain \\
\hline & Çağlayan & Kars - Çağlayan Village & Light brown spike, awny, amber grain \\
\hline & Şahmelik & $\begin{array}{l}\text { Kayseri } \\
\text { Develi - Şahmelik Village }\end{array}$ & White spike, awny, amber grain \\
\hline \multirow{2}{*}{ 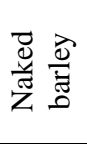 } & Özen & $\begin{array}{l}\text { Field Crops Central Research Institute - } \\
\text { Ankara }\end{array}$ & Spring, 2-rows, medium early, medium height, awny, white-amber grain \\
\hline & Yalin & $\begin{array}{l}\text { Field Crops Central Research Institute - } \\
\text { Ankara }\end{array}$ & $\begin{array}{l}\text { Alternative, 2-rows, medium late, medium height, awny, white-amber } \\
\text { grain }\end{array}$ \\
\hline
\end{tabular}

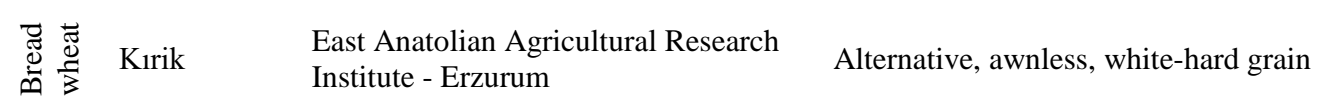

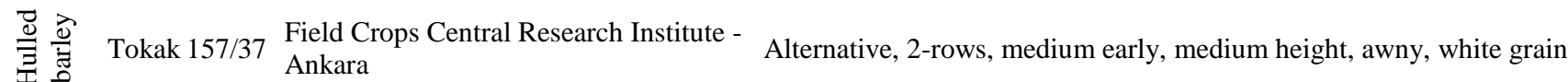


Öztürk et al. - Journal of Agricultural Sciences (Tarım Bilimleri Dergisi), 2021, 27(2): 195-203

Table 2- Some climate data of study years and long-term mean (LTM: 1990-2016) in Erzurum province

\begin{tabular}{|c|c|c|c|c|c|c|c|c|c|c|}
\hline \multirow[t]{2}{*}{ Months } & \multicolumn{3}{|c|}{$\begin{array}{l}\text { Total } \\
\text { rainfall }(\mathrm{mm}) \\
\end{array}$} & \multicolumn{3}{|c|}{$\begin{array}{l}\text { Average } \\
\text { temperature }\left({ }^{\circ} \mathrm{C}\right)\end{array}$} & \multicolumn{2}{|c|}{$\begin{array}{l}\text { Minimum } \\
\text { temperature }\left({ }^{\circ} \mathrm{C}\right)\end{array}$} & \multicolumn{2}{|c|}{$\begin{array}{l}\text { Maximum } \\
\text { temperature }\left({ }^{\circ} \mathrm{C}\right)\end{array}$} \\
\hline & 2017 & 2018 & $L T M$ & 2017 & 2018 & $L T M$ & 2017 & 2018 & 2017 & 2018 \\
\hline April & 44.8 & 11.0 & 57.5 & 5.6 & 7.4 & 5.5 & -8.4 & -18.1 & 12.7 & 19.8 \\
\hline May & 59.0 & 140.0 & 66.3 & 10.6 & 11.3 & 10.5 & -1.1 & 2.3 & 17.9 & 21.8 \\
\hline June & 12.6 & 76.8 & 43.5 & 15.7 & 14.6 & 14.9 & 1.2 & 3.7 & 24.3 & 30.8 \\
\hline July & 6.8 & 24.8 & 23.4 & 20.8 & 20.1 & 19.2 & 6.0 & 4.2 & 30.6 & 24.4 \\
\hline August & 15.2 & 33.0 & 15.7 & 21.6 & 19.8 & 19.5 & 4.4 & 6.3 & 31.1 & 32.3 \\
\hline Total/Average & 138.4 & 285.6 & 206.4 & 14.9 & 14.6 & 13.9 & & & & \\
\hline
\end{tabular}

The length of the vegetative period (VP) was taken as the number of days from sowing to anthesis. The length of the grainfilling period (GFP) was taken as the number of days from anthesis to physiological maturity. Anthesis was defined as the period when $50 \%$ of the spikes had anthers extruding, and physiological maturity was defined as the period when $50 \%$ of the glumes of the spikes had turned yellow. Plant height was measured from soil surface to top of spikes. Spikes per $\mathrm{m}^{2}$ were determined from a 1-m row sample. Ten spikes were randomly harvested from within plots for the determination of kernels per spike. At maturity, the plots were trimmed to $4.5 \mathrm{~m}$, and the four inner rows were harvested with a plot combine, and the weight of cleaned grain from each plot was recorded. Kernel weight was determined based on 4x100 kernel samples. Grain protein content was determined by near-infrared spectroscopy (model NIRS DS2500, Foss, Denmark) calibrated based on official AACC method 39-10 (AACC 2010). Grain samples of the einkorn and emmer landraces were dehulled before protein was determined.

The years and treatments were considered to be random, while genotypes were considered to be fixed. The analysis of variance was performed with the SAS GLM (SAS Inst., Cary, NC) software package. When significant genotype effects were detected, Duncan's Multiple Range Test was used to determine the differences among the genotypes. Data were combined over the years and presented as a 2-year mean values.

\section{Results and Discussion}

The soil moisture content at sowing time was sufficient, and crops usually germinated normally in both years. In the irrigated plots, lodging occurred at the early grain-filling stage and it was visually scored as a percent of the plot. Lodging in the einkorn landraces plots was 20-30\%, emmer landraces plots were 40-60\%, and the other cultivars plots was $10-20 \%$. In 2017 , there was no damage related to pests or diseases. In 2018, rust diseases were observed on all the genotypes and no disease control was done.

The results of the analysis of variance showed that most of the agronomic characteristics (except 1000-kernel weight) were significantly influenced depending on year. Favorable climatic conditions during the growth cycle in 2018 increased vegetative period, grain filling period, plant height, number of spike per square-meter, grain number per spike, grain yield, and harvest index, but decreased crude protein content (Tables 3, 4 and 5). The genotype and treatment factors had a significant effect on all the traits studied. Except for grain number per spike, year x genotype interactions were highly significant in terms of the investigated traits. Year $x$ treatment interactions were significant in terms of the vegetative period, plant height, number of spike per square-meter and 1000-kernel weight. Genotype $\times$ treatment interaction effect was significant in terms of the vegetative period, grain filling period, plant height, number of spike per square-meter, 1000-kernel weight, grain yield and harvest index.

\subsection{Vegetative period, grain filling period and plant height}

Vegetative period and grain-filling period are critical periods in terms of accumulation of adequate storage capacity for grain filling and kernel weight. Vegetative periods of genotypes ranged between 59.3-71.7 days in irrigated and 58.2-71.0 days in rainfed conditions (Table 3). In both growing conditions, Tokak 157/37 cultivar had the shortest while Enbiya and Y1ldirımtepe genotypes had the longest vegetative period. Karagöz \& Zencirci (2005) pointed out that the vegetative period of einkorn, emmer and bread wheat were 17.0 days, 11.1 days and 14.0 days, respectively, and there were significant variations among them. Moreover, they reported that the average vegetative period was the shortest bread wheat and longest einkorn type. Ear of emmer wheat emerged eight days before einkorn wheat under Italian conditions (Troccoli \& Codianni 2005). Ottekin et al. (1996) reported that naked barley genotypes matured earlier in comparison with hulled barley genotypes. It was determined in this study that einkorn and emmer wheat genotypes had a similar vegetative period with Kurik bread wheat genotype while naked barley had a similar vegetative period with Tokak 157/37 cultivar. Irrigation extended the vegetative period one more day as an average of genotypes, when compared to rain-fed condition.

Grain filling period of genotypes ranged between 29.8-38.0 days in irrigated conditions while it was 26.7-33.8 days in rainfed (Table 3). The einkorn genotypes had the same grain filling period as the Kirik cultivar whereas naked barley cultivars had a longer grain filling period than Tokak 157/37. The average grain filling period was 34.2 days in irrigation conditions and decreased to 31.0 days in dry farming conditions. It is obvious that moisture insufficiency limits the grain filling period (Frederick \& Camberato 1995; Öztürk 1999 a). The longest grain filling period in both irrigated and dry farming conditions was observed 
in Yalın and Özen varieties while the shortest grain filling period was observed in Yıldırımtepe and Şahmelik genotypes. The response of genotypes to growing conditions was different in terms of the grain-filling period. Rain-fed conditions reduced the grain filling period to 4.2 days in Özen variety and 1.8 days in Çağlayan population.

Table 3- Vegetative period, grain filling period and plant height of the alternative cereal genotypes grown under irrigated and rain-fed conditions ${ }^{1}$

\begin{tabular}{|c|c|c|c|c|c|c|c|c|c|}
\hline \multirow[b]{2}{*}{ Genotypes } & \multicolumn{3}{|c|}{ Vegetative period (days) } & \multicolumn{3}{|c|}{ Grain filling period (days) } & \multicolumn{3}{|c|}{ Plant height $(\mathrm{cm})$} \\
\hline & Irrigated & Rain-fed & Mean & Irrigated & Rain-fed & Mean & Irrigated & Rain-fed & Mean \\
\hline$\overline{\text { Çatalyazi }^{\text {Ein }}}$ & 71.2 & 70.7 & $70.9^{\mathrm{a}}$ & 34.7 & 31.0 & $32.8^{\mathrm{b}}$ & 97.8 & 93.5 & $95.7^{\mathrm{bc}}$ \\
\hline Enbiya $^{\text {Ein }}$ & 71.5 & 71.0 & $71.3^{\mathrm{a}}$ & 34.5 & 31.5 & $33.0^{\mathrm{b}}$ & 105.2 & 99.0 & $102.1^{\mathrm{a}}$ \\
\hline Musasofular ${ }^{\text {Ein }}$ & 71.2 & 70.3 & $70.8^{\mathrm{a}}$ & 34.5 & 32.2 & $33.3^{\mathrm{b}}$ & 98.9 & 95.2 & $97.1^{\mathrm{b}}$ \\
\hline Yildırımtepe $^{E m}$ & 71.7 & 71.0 & $71.3^{\mathrm{a}}$ & 29.8 & 26.7 & $28.3^{\mathrm{d}}$ & 89.3 & 93.1 & $91.2^{\mathrm{d}}$ \\
\hline Çağlayan ${ }^{E m}$ & 65.7 & 64.3 & $65.0^{\mathrm{c}}$ & 34.0 & 32.2 & $33.1^{\mathrm{b}}$ & 94.1 & 90.8 & $92.5^{\mathrm{cd}}$ \\
\hline Şahmelik ${ }^{E m}$ & 71.2 & 67.5 & $69.3^{\mathrm{b}}$ & 30.8 & 26.7 & $28.8^{\mathrm{d}}$ & 93.7 & 92.0 & $92.8^{\mathrm{cd}}$ \\
\hline Yalın $^{N b}$ & 64.3 & 64.2 & $64.3^{\mathrm{d}}$ & 37.5 & 33.7 & $35.6^{\mathrm{a}}$ & 79.6 & 79.1 & $79.3^{\mathrm{e}}$ \\
\hline Özen ${ }^{N b}$ & 64.7 & 64.8 & $64.8^{\mathrm{cd}}$ & 38.0 & 33.8 & $35.9^{\mathrm{a}}$ & 96.8 & 86.2 & $91.5^{\mathrm{d}}$ \\
\hline $\mathrm{K}_{1 \mathrm{rik}}{ }^{B w}$ & 71.2 & 70.3 & $70.8^{\mathrm{a}}$ & 34.7 & 32.2 & $33.4^{\mathrm{b}}$ & 99.8 & 96.5 & $98.1^{\mathrm{b}}$ \\
\hline Tokak $157 / 37^{H b}$ & 59.3 & 58.2 & $58.8^{\mathrm{e}}$ & 33.7 & 30.5 & $32.1^{\mathrm{c}}$ & 83.3 & 80.3 & $81.8^{\mathrm{e}}$ \\
\hline Mean & $68.2^{\mathrm{a}}$ & $67.2^{\mathrm{b}}$ & 67.7 & $34.2^{\mathrm{a}}$ & $31.0^{\mathrm{b}}$ & 32.6 & $93.8^{\mathrm{a}}$ & $90.6^{\mathrm{b}}$ & 92.2 \\
\hline 2017 & 67.0 & 65.5 & $66.3^{\mathrm{b}}$ & 33.4 & 30.2 & $31.8^{\mathrm{b}}$ & 84.1 & 76.0 & $80.1^{\mathrm{b}}$ \\
\hline 2018 & 69.4 & 69.0 & $69.2^{\mathrm{a}}$ & 35.1 & 31.8 & $33.5^{\mathrm{a}}$ & 103.6 & 105.1 & $104.4^{\mathrm{a}}$ \\
\hline \multicolumn{10}{|l|}{ F values } \\
\hline Year (Y) & & & $5104.2 * *$ & & & $280.0 * *$ & & & $1906.9 * *$ \\
\hline Genotype (G) & & & $770.9 * *$ & & & $196.1 * *$ & & & $47.1 * *$ \\
\hline Treatment $(\mathrm{T})$ & & & $541.5^{* *}$ & & & $1042.3 * *$ & & & $34.2 * *$ \\
\hline$Y \times G$ & & & $10.5^{* *}$ & & & $3.6^{* *}$ & & & $25.6 * *$ \\
\hline $\mathrm{Y} \times \mathrm{T}$ & & & $81.5^{* *}$ & & & 0.3 & & & $74.9 * *$ \\
\hline $\mathrm{G} \times \mathrm{T}$ & & & $11.6^{* *}$ & & & $5.0 * *$ & & & $3.3^{* *}$ \\
\hline$Y \times G \times T$ & & & $9.4 * *$ & & & $2.9 * *$ & & & $2.2 *$ \\
\hline $\mathrm{CV}(\%)$ & & & 0.8 & & & 1.9 & & & 3.9 \\
\hline
\end{tabular}

${ }^{1}$ The means marked with the same letter are not significantly different; $\mathrm{F}$ values marked with * and ** are significant at 0.05 and 0.01 levels, respectively. (Ein: einkorn, Em: emmer, $\mathrm{Nb}$ : naked barley, Bw: bread wheat, Hb: hulled barley)

Plant heights of genotypes were measured between 79.6 and $105.2 \mathrm{~cm}$ in irrigated conditions and 79.1 and $99.0 \mathrm{~cm}$ in rainfed conditions. (Table 3). In both growing conditions, the longest plant height was measured in Enbiya genotype and the shortest height in Yalın cultivar. Genotypes may differ in terms of plant height depending on vegetative period length, the number of internodes and internode length. It is possible to note that Troccoli \& Codianni (2005) measured a longer plant height with 116 $\mathrm{cm}$ in einkorn and $127 \mathrm{~cm}$ in emmer, when compared to the results of this study. Karagöz \& Zencirci (2005) determined that the plant height of einkorn and emmer wheat genotypes changed between 79.1-104.4 and 63.8-102.1 cm, respectively. In addition, the plant height of hulled and naked barley genotypes was determined to change between $50-84 \mathrm{~cm}$ and $38-82 \mathrm{~cm}$, respectively by Ottekin et al. (1996). The value of hulled barley was respectively measured as $46.9-73.7 \mathrm{~cm}$ and $40.9-56.1 \mathrm{~cm}$ by TobiaszSalach et al. (2012) and Öztürk et al. (2001). The findings obtained in our study in terms of plant height was generally in agreement with the findings of these researchers. Plant height as the average of genotypes was $93.8 \mathrm{~cm}$ in irrigated conditions. However, it decreased significantly in rain-fed conditions and was determined as $90.6 \mathrm{~cm}$. Plant height, which is a droughtsensitive character (Gomez-Macpherson \& Richards 1995), is mainly affected by environmental conditions between booting and heading. During this period, the lack of moisture reduces plant height by shortening the nodes. Although the lack of moisture in late development periods had a less negative impact on plant height, plant height decreased significantly in rain-fed conditions.

\subsection{Spike number per $m^{2}$, grain number per spike and 1000-kernel weight}

The spike number per $\mathrm{m}^{2}$ of genotypes ranged between 533.3-682.5 in irrigated and 457.5-573.3 in dry farming conditions. The highest number of spikes per square meter was recorded in Musasofular and Çatalyazı and the lowest was in Özen and Yalın genotypes (Table 4). The number of spike per square-meter of genotypes may diverge depending on the degree of tillering and the ability to maintain fertile tiller until harvest. The spike number of einkorn and emmer genotypes in this study was higher than the values (416-442) obtained by Troccoli \& Codiannni (2005) under Italian conditions. The spike number of naked genotypes was higher than the values (196-389) obtained in Iran conditions by Balouchi et al. (2005). However, it was similar to the values (413-513) obtained in Poland conditions by Tobiasz-Salach et al. (2012). Number of spike per square-meter, which was 593.3 in irrigated conditions, was 506.8 due to the decrease in the fertility tiller rate in rain-fed conditions. The number of potential spikes in the unit area is mainly determined by the development processes and environmental conditions up to the beginning of the booting. However, the ability to maintain the number of fertile tillers until harvest is an important attribute that contributes to grain yield in rain-fed conditions (Öztürk 1999 b). 
Öztürk et al. - Journal of Agricultural Sciences (Tarım Bilimleri Dergisi), 2021, 27(2): 195-203

Table 4- Spike number per $\mathrm{m}^{2}$, grain number per spike and 1000-kernel weight of the alternative cereal genotypes grown under irrigated and rain-fed conditions ${ }^{1}$

\begin{tabular}{|c|c|c|c|c|c|c|c|c|c|}
\hline \multirow[b]{2}{*}{ Genotypes } & \multicolumn{3}{|c|}{ Spike number per $\mathrm{m}^{2}$} & \multicolumn{3}{|c|}{ Grain number per spike } & \multicolumn{3}{|c|}{ 1000-kernel weight (g) } \\
\hline & Irrigated & Rain-fed & Mean & Irrigated & Rain-fed & Mean & Irrigated & Rain-fed & Mean \\
\hline Çatalyazi ${ }^{\text {Ein }}$ & 618.3 & 573.3 & $595.8^{\mathrm{ab}}$ & 16.4 & 14.3 & $15.4^{\mathrm{d}}$ & 32.0 & 28.0 & $30.0^{\mathrm{g}}$ \\
\hline Enbiya $^{\text {Ein }}$ & 638.3 & 552.5 & $595.4^{\mathrm{ab}}$ & 16.1 & 13.6 & $14.8^{\mathrm{d}}$ & 34.5 & 30.0 & $32.2^{\mathrm{f}}$ \\
\hline Musasofular Ein & 682.5 & 546.7 & $614.6^{\mathrm{a}}$ & 16.6 & 14.2 & $15.4^{\mathrm{d}}$ & 34.4 & 31.2 & $32.8^{\mathrm{ef}}$ \\
\hline Yildirımtepe $^{E m}$ & 605.0 & 540.8 & $572.9^{\mathrm{bc}}$ & 18.9 & 17.0 & $18.0^{\mathrm{c}}$ & 36.2 & 33.3 & $34.7^{\mathrm{d}}$ \\
\hline Çağlayan ${ }^{E m}$ & 579.2 & 514.2 & $546.7^{\mathrm{cd}}$ & 19.7 & 18.7 & $19.2^{\mathrm{bc}}$ & 35.2 & 32.9 & $34.0^{\mathrm{de}}$ \\
\hline Şahmelik ${ }^{E m}$ & 580.8 & 468.3 & $524.6^{\mathrm{d}}$ & 21.0 & 19.3 & $20.1^{\mathrm{ab}}$ & 38.5 & 36.1 & $37.3^{\mathrm{c}}$ \\
\hline Yalın $^{N b}$ & 533.3 & 483.3 & $508.3^{\mathrm{d}}$ & 21.0 & 18.5 & $19.8^{\mathrm{abc}}$ & 41.6 & 39.3 & $40.5^{\mathrm{b}}$ \\
\hline Özen ${ }^{N b}$ & 575.8 & 457.5 & $516.7^{\mathrm{d}}$ & 20.0 & 18.9 & $19.5^{\mathrm{abc}}$ & 42.0 & 39.9 & $40.9^{\mathrm{b}}$ \\
\hline $\mathrm{K}_{1 \mathrm{rik}}{ }^{B w}$ & 566.7 & 466.7 & $516.7^{\mathrm{d}}$ & 22.6 & 20.0 & $21.3^{\mathrm{a}}$ & 31.2 & 29.1 & $30.2^{\mathrm{g}}$ \\
\hline Tokak $157 / 37^{H b}$ & 552.5 & 464.2 & $508.3^{\mathrm{d}}$ & 20.1 & 19.7 & $19.9^{\mathrm{ab}}$ & 54.6 & 47.6 & $51.1^{\mathrm{a}}$ \\
\hline $\begin{array}{r}\text { Mean } \\
\end{array}$ & $593.3^{\mathrm{a}}$ & $506.8^{\mathrm{b}}$ & 550.0 & $19.2^{\mathrm{a}}$ & $17.4^{\mathrm{b}}$ & 18.3 & $38.0^{\mathrm{a}}$ & $34.7^{\mathrm{b}}$ & 36.4 \\
\hline 2017 & 538.3 & 478.2 & $508.3^{\mathrm{b}}$ & 17.6 & 16.7 & $17.1^{\mathrm{b}}$ & 38.7 & 34.0 & 36.3 \\
\hline 2018 & 648.2 & 535.3 & $591.8^{\mathrm{a}}$ & 20.9 & 18.2 & $19.5^{\mathrm{a}}$ & 37.4 & 35.5 & 36.4 \\
\hline \multicolumn{10}{|l|}{ F values } \\
\hline Year $(\mathrm{Y})$ & & & $428.1 * *$ & & & $45.2 * *$ & & & 0.1 \\
\hline Genotype (G) & & & $18.6 * *$ & & & $25.5^{* *}$ & & & $295.6 * *$ \\
\hline Treatment $(\mathrm{T})$ & & & $459.5 * *$ & & & $26.5 * *$ & & & $86.8 * *$ \\
\hline$Y \times G$ & & & $9.8 * *$ & & & 0.9 & & & $58.5 * *$ \\
\hline $\mathrm{Y} \times \mathrm{T}$ & & & $42.6 * *$ & & & 6.4 & & & $16.0^{*}$ \\
\hline $\mathrm{G} \times \mathrm{T}$ & & & $2.6^{*}$ & & & 0.7 & & & $4.2 * *$ \\
\hline $\mathrm{Y} \times \mathrm{G} \times \mathrm{T}$ & & & $2.2 *$ & & & 0.2 & & & $3.6 * *$ \\
\hline $\mathrm{CV}(\%)$ & & & 6.0 & & & 8.7 & & & 3.6 \\
\hline
\end{tabular}

${ }^{1}$ The means marked with the same letter are not significantly different; F values marked with * and $* *$ are significant at 0.05 and 0.01 levels, respectively. (Ein: einkorn, Em: emmer, Nb: naked barley, Bw: bread wheat, Hb: hulled barley)

Grain number of genotypes varied from 16.1 to 22.6 in irrigated condition while it varied from 13.6 to 20.0 in rain-fed condition. In this study, it was found that Kırik, Şahmelik and Yalın genotypes in irrigated condition and Kırik, Tokak 157/37 and Şahmelik genotypes in rain-fed condition had the highest grain number (Table 4). Moreover, the lowest grain number per spike was observed in einkorn genotypes under both growth conditions. Since the number of the fertile spikelet in the spike and the number of fertile flowers in the spikelet differ from genotype to genotype, significant differences may occur between genotypes in terms of grain number in the spike. The number of grains per spike for einkorn and emmer wheat was determined to change between 13.6-36.6 and 15.4-39.6, respectively in Ankara condition by Karagöz \& Zencirci (2005) and again ranged from 13.8 to 17.8, respectively in Czech Republic condition by Konvalina et al. (2010). In the studies on naked barley genotypes, the number of grains per spike for genotypes was reported to be between 21 and 54 under Iranian condition (Balouchi et al. 2005) and 14.7-23.6 under Polish conditions (Tobiasz-Salach et al. 2012). Drought can limit the number of grains in the spike by reducing both the number of the spikelet in the spike and flowers in the spikelet and causing the death of fertilized flowers. The number of grains per spike was 19.2 in irrigated conditions, whereas it was recorded as 17.4 in rain-fed agriculture. Although the number of potential grains in spike is mainly determined by pre-spike development processes and environmental conditions, the deficiency of moisture after anthesis may reduce the number of fertile flowers in spikes away from the center of the spike. Both Öztürk (1999a) and Bogale \& Tesfaye (2011) reported that the late drought significantly reduced the grain number of a spike compared to irrigated conditions.

According to the results obtained in this study, the 1000-kernel weight of genotypes ranged between 31.2 and $54.6 \mathrm{~g}$ in irrigated and 28.0 and $47.6 \mathrm{~g}$ in rain-fed conditions. Tokak 157/37 cultivar had the highest 1000-kernel weight in both growing conditions. On the other hand, the lowest 1000-kernel weight was determined in Kirik genotype in irrigated condition and Çatalyazı genotypes in rain-fed agricultural condition (Table 4). The grain weight is also influenced by the dynamic balance between the yield components, but is mainly determined by post-flowering development processes and environmental conditions (Wiegand et al. 1981). Grain weight is a common function of the grain filling period and grain filling rate, and genotypic variation in these characters gives rise to significant differences in terms of 1000 grain weight. 1000-kernel weights for einkorn and emmer wheat genotypes were determined between 28.5 and 38.8 g and 29.5 and 34.7 g, respectively, by Karagöz \& Zencirci (2005) and these findings were similar to ours. Unlike our findings, Konvalina et al. (2010) reported that the kernel weight was between 23.8 and $28.1 \mathrm{~g}$ and 36.9 and $46.1 \mathrm{~g}$ for these genotypes, respectively. This value in the studies conducted on genotypes of naked barley was determined to be between 29.0 and $43.3 \mathrm{~g}, 24$ and $47 \mathrm{~g}$ and 37.3 and $49.4 \mathrm{~g}$ by Ottekin et al. (1996), Balouchi et al. (2005) and Tobiasz-Salach et al. (2012), respectively, and significant genotypic differences were noted. The shortage of moisture decreases 1000 grain weight by reducing grain filling period and increasing leaf senescence (Öztürk 1999 b; Hafsi et al. 2000). The 1000-kernel weight was $38.0 \mathrm{~g}$ in irrigated condition with respect to the average of crop years and genotypes, but decreased in all genotypes under rain-fed conditions and was an average of $34.7 \mathrm{~g}$. 


\subsection{Grain yield, harvest index and crude protein content}

The more favorable climatic conditions in 2018 increased number of spike per square-meter and the number of grains per spike, and the grain yield was significantly higher than the one in 2017 . Grain yields of genotypes ranged between $2410-4099 \mathrm{~kg}^{-1}$ in irrigated conditions and 1716-2660 $\mathrm{kg} \mathrm{ha}^{-1}$ in rain-fed conditions (Table 5). Tokak 157/37 cultivar had the highest grain yield in irrigated and rain-fed conditions, followed by Özen and Yalın naked barley varieties. The lowest grain yields were obtained from Yildırımtepe and Şahmelik genotypes in irrigated conditions and Kırik and Enbiya genotypes in rain-fed conditions. Grain yield of Kırik genotype under rain-fed condition was similar to the values (1635-1734 kg ha-1) obtained by Öztürk et al. (2006) under Erzurum condition while its grain yield in irrigated condition was higher than the value ( $\left.2470 \mathrm{~kg} \mathrm{ha}^{-1}\right)$ obtained by Salantur et al. (2006). Grain yield of Tokak $157 / 37$ cultivar is higher than the values obtained by Öztürk et al. (2001) and Çağlar et al. (2009) (2576 and $2250 \mathrm{~kg} \mathrm{ha}^{-1}$, respectively) in Erzurum irrigated agricultural conditions. In this study, grain yields obtained from einkorn (1895-3025 kg ha-1) and emmer (2228-3095 kg ha-1) genotypes were lower than the yields determined in einkorn (1895$3025 \mathrm{~kg} \mathrm{ha}^{-1}$ ) and emmer (2228-3095 kg ha-1) genotypes by Kaplan et al. (2014) under Kayseri condition. Troccoli \& Codianni (2005) obtained 1690 and $3850 \mathrm{~kg} \mathrm{ha}^{-1}$ grain yields from einkorn and emmer populations in Italy condition, respectively. The grain yields of emmer genotypes were determined to range between $2579-3293 \mathrm{~kg} \mathrm{ha}^{-1}$ in the Czech Republic (Konvalina et al. 2012) and 2480-2500 kg ha-1 in the US condition (Kucek et al. 2017). The grain yield in naked barley was reported between 1617 and $3420 \mathrm{~kg} \mathrm{ha}^{-1}$ in Ankara condition (Ottekin et al. 1996) and 3390 and $4510 \mathrm{~kg} \mathrm{ha}^{-1}$ in England condition (Dickin et al. 2012). Grain yield of $3007 \mathrm{~kg} \mathrm{ha}^{-1}$ in irrigated condition decreased by $26.2 \%$ as a result of the negative effect of moisture insufficiency on yield components (spike number per $\mathrm{m}^{2}$, grain number per spike and grain weight reduction rates $14.6 \%, 9.4 \%$ and $8.7 \%$, respectively), and it was identified as $2218 \mathrm{~kg} \mathrm{ha}^{-1}$ under rain-fed conditions. Öztürk (1999a) determined that grain yield of winter bread wheat decreased by $30.5 \%$ in rain-fed agricultural conditions compared to irrigated agricultural conditions. The grain yields of all genotypes in this study reduced in rain-fed conditions compared to irrigated agricultural conditions. Grain yield losses in rain-fed conditions may vary according to genotypes owing to differences in the response of genotypes to rainfed conditions in terms of grain yield. The decrease rates of grain yield in rain-fed agricultural conditions were the lowest in Yıldırımtepe (7.6\%) and Şahmelik (8.3\%) genotypes while the highest in Kırik (40.4\%) and Tokak 157/37 (35.1\%) varieties.

Table 5- Grain yield, harvest index and crude protein content of the alternative cereal genotypes grown under irrigated and rain-fed conditions ${ }^{1}$

\begin{tabular}{|c|c|c|c|c|c|c|c|c|c|}
\hline \multirow{2}{*}{ Genotypes } & \multicolumn{3}{|c|}{ Grain yield $\left(\mathrm{kg} \mathrm{ha}^{-1}\right)$} & \multicolumn{3}{|c|}{ Harvest index $(\%)$} & \multicolumn{3}{|c|}{ Crude protein content $(\%)$} \\
\hline & Irrigated & Rain-fed & Mean & Irrigated & Rain-fed & Mean & Irrigated & Rain-fed & Mean \\
\hline Çatalyazi $^{\text {Ein }}$ & 3025 & 1989 & $2507^{\mathrm{bcd}}$ & 25.8 & 20.8 & $23.3^{\mathrm{b}}$ & 13.0 & 14.7 & $13.8^{\mathrm{a}}$ \\
\hline Enbiya $^{\text {Ein }}$ & 2793 & 1895 & $2344^{\mathrm{d}}$ & 24.6 & 21.7 & $23.2^{b}$ & 13.2 & 14.8 & $14.0^{\mathrm{a}}$ \\
\hline MusasofularEin & 2749 & 2027 & $2388^{\mathrm{cd}}$ & 24.4 & 22.6 & $23.5^{b}$ & 13.5 & 14.5 & $14.0^{\mathrm{a}}$ \\
\hline Yildırımtepe $e^{E m}$ & 2410 & 2228 & $2319^{d}$ & 24.7 & 24.5 & $24.6^{\mathrm{b}}$ & 11.7 & 13.0 & $12.3^{\mathrm{cd}}$ \\
\hline Çağlayan ${ }^{E m}$ & 3095 & 2259 & $2677^{\text {bcd }}$ & 25.8 & 22.4 & $24.1^{\mathrm{b}}$ & 12.8 & 13.8 & $13.3^{\mathrm{ab}}$ \\
\hline Şahmelik ${ }^{E m}$ & 2576 & 2363 & $2469^{\mathrm{cd}}$ & 25.7 & 24.1 & $24.9^{b}$ & 12.3 & 13.0 & $12.6^{\mathrm{bc}}$ \\
\hline Yalın $^{N b}$ & 3097 & 2536 & $2816^{\mathrm{bc}}$ & 30.1 & 27.3 & $28.7^{\mathrm{a}}$ & 10.1 & 10.4 & $10.3^{\mathrm{e}}$ \\
\hline Özen ${ }^{N b}$ & 3346 & 2508 & $2927^{b}$ & 28.4 & 27.8 & $28.1^{\mathrm{a}}$ & 10.9 & 12.7 & $11.8^{\mathrm{d}}$ \\
\hline $\mathrm{K}_{1 \mathrm{rik}}{ }^{B w}$ & 2881 & 1716 & $2299^{d}$ & 27.8 & 19.7 & $23.7^{b}$ & 12.5 & 13.4 & $13.0^{\mathrm{bc}}$ \\
\hline Tokak $157 / 37^{H b}$ & 4099 & 2660 & $3380^{\mathrm{a}}$ & 34.1 & 22.7 & $28.4^{\mathrm{a}}$ & 11.6 & 12.0 & $11.8^{\mathrm{d}}$ \\
\hline Mean & $3007^{a}$ & $2218^{b}$ & 2612 & $27.1^{\mathrm{a}}$ & $23.4^{\mathrm{b}}$ & 25.3 & $12.2^{b}$ & $13.2^{\mathrm{a}}$ & 12.7 \\
\hline 2017 & 2613 & 1727 & $2170^{\mathrm{b}}$ & 23.6 & 20.3 & $22.0^{\mathrm{b}}$ & 12.5 & 13.6 & $13.0^{\mathrm{a}}$ \\
\hline 2018 & 3401 & 2709 & $3055^{\mathrm{a}}$ & 30.7 & 26.4 & $28.5^{\mathrm{a}}$ & 11.8 & 12.9 & $12.4^{\mathrm{b}}$ \\
\hline \multicolumn{10}{|l|}{ F values } \\
\hline Year $(Y)$ & & & $459.5 * *$ & & & $55.0 * *$ & & & $27.5 * *$ \\
\hline Genotype (G) & & & $10.8 * *$ & & & $2.9 * *$ & & & $33.3 * *$ \\
\hline Treatment (T) & & & $365.4 * *$ & & & $18.2 *$ & & & $72.3 * *$ \\
\hline$Y \times G$ & & & $6.9 * *$ & & & $2.8 * *$ & & & $2.3^{*}$ \\
\hline $\mathrm{Y} \times \mathrm{T}$ & & & 5.5 & & & 0.3 & & & 0.1 \\
\hline $\mathrm{G} \times \mathrm{T}$ & & & $3.5 * *$ & & & 1.8 & & & 1.6 \\
\hline$Y \times G \times T$ & & & 1.2 & & & 1.2 & & & 0.6 \\
\hline $\mathrm{CV}(\%)$ & & & 14.0 & & & 18.0 & & & 5.6 \\
\hline
\end{tabular}

${ }^{1}$ The means marked with the same letter are not significantly different; F values marked with $*$ and $* *$ are significant at 0.05 and 0.01 levels, respectively. (Ein: einkorn, Em: emmer, Nb: naked barley, Bw: bread wheat, Hb: hulled barley)

Harvest indexes of genotypes ranged between 24.4 and $34.1 \%$ in irrigated and 19.7 and $27.8 \%$ in rain-fed conditions. The highest harvest indexes in irrigated agricultural conditions were obtained from Tokak 157/37, Özen and Yalın genotypes, respectively, whereas the lowest ones were obtained from Musasofular and Enbiya genotypes. Yalın and Özen genotypes had the highest harvest index in rain-fed agricultural condition while Kırik and Çatalyazı genotypes had the lowest harvest index. As a result of differences in total dry matter production and assimilate distribution, genotypes may be significantly different in point of harvest index (Karimi \& Siddique 1991). The recent breeding strategy has increased the number of grains per unit area and the harvest index with high plant fertility, stiffness of the plant, shortening of plant height, and high spike fertility. The recent breeding strategy in cereals has led to an increase in the resistance to lodging due to shortening of plant height, and also in harvest index and grain number per unit area due to more spike fertility (Guarda et al. 2004). Öztürk (1999 a) found that wheat genotypes 
were significantly different in way of harvest index and also calculated them between $29.9-41.3 \%$ in irrigated and $30.4-38.5 \%$ in rain-fed conditions. The harvest indexes in einkorn genotypes and emmer genotypes, respectively, were determined to range from $29.9 \%$ to $36.3 \%$ and from $27.6 \%$ to $33.3 \%$ by Kaplan et al. (2014), while they respectively changed from $30 \%$ to $40 \%$ and from $30 \%$ to $40 \%$ according to Konvalina et al. (2010). These values are higher than our findings. Furthermore, while the harvest index was $27.1 \%$ in irrigated conditions, it significantly decreased and was $23.4 \%$ in rain-fed agricultural conditions. The negative effect of moisture deficiency on grain yield is more than the negative effect on stem yield. Other researchers also reported that a moisture deficiency reduced the harvest index (Öztürk 1999a; Bogale \& Tesfaye 2011).

The fact that the post-heading period was cooler and more humid in the second year of the research caused the crude protein ratio to be lower compared to 2017 . While the crude protein contents of grain genotypes ranged between $10.1 \%$ and $13.5 \%$ in irrigated condition; $10.4 \%$ and $14.8 \%$ in rain-fed condition. The lowest crude protein content was determined in Yalın cultivar in both growing conditions. Musasofular had the highest crude protein ratio in irrigated condition, followed by other Enbiya and Çatalyazı einkorn wheat genotypes. As in irrigated condition, the highest crude protein content in rain-fed condition was obtained from einkorn wheat populations such as Enbiya, Çatalyazı and Musasofular. The grain protein content is the most important indicator of the nutritional value and quality of the product and it is likely to be considered as alternative cereal genotypes in this aspect. In terms of grain protein ratio, the einkorn wheat type was the most superior, emmer genotypes and Kirik cultivar was similar in the middle order and barley varieties were in the last order with the lowest crude protein contents. The crude protein contents obtained from einkorn species were similar to the values (7.30-15.99\%, 14.2-16.6\% and 11.6-13.9\%, respectively) reported by Kaplan et al. (2014), Konvalina et al. (2013) and Geisslitza et al. (2018), while they were lower than the value (15.5$22.8 \%$ ) reported by Brandolini et al. (2008). Crude protein contents of emmer populations were significantly lower than the values that varied between $16.1 \%-19.0 \%$ according to Konvalina et al. (2012), $14.7 \%-18.9 \%$ according to Konvalina et al. (2013), and 14.2\%-15.0\% according to Kucek et al. (2017), while they were similar to the values (11.2-12.4\%) reported by Geisslitza et al. (2018). In naked barley genotypes, the values which were determined as 13.2-19.5\% by Ottekin et al. (1996), 12.55-15.92\% by Helm \& Francisco (2004) and 12.6-16.1\% by Tobiasz-Salach et al. (2012) were higher than ours. However, Balouchi et al. (2005) determined lower protein contents (7.21-11.61\%) in comparison with our results. The crude protein content was $12.2 \%$ in irrigated condition, whereas it significantly increased and reached up to $13.2 \%$ in rain-fed conditions. It is clear that lack of moisture after anthesis increases the amount of nitrogen accumulated in the grain per unit starch by reducing the synthesis and storage of carbohydrates (Panozzo \& Eagles 2000, Öztürk \& Aydin 2004).

\section{Conclusions}

This study provides important data about the agricultural potential of einkorn wheat, emmer wheat and naked barley genotypes which were grown in spring under irrigated and rain-fed agriculture conditions. The highest grain yield was obtained from Tokak $157 / 37$ barley cultivar and the highest protein ratio from einkorn genotypes. When the average of genotypes was taken into consideration, it is possible to state that the number of spike per square-meter, grain number per spike, 1000-kernel weight and grain yield decreased by $14.6 \%, 9.4 \%, 8.7 \%$ and $26.2 \%$, respectively in rain-fed condition compared to irrigated condition while crude protein content increased by $8.2 \%$. It was concluded that naked barley cultivars of Özen and Yalın cannot be an alternative to Tokak 157/37 barley cultivar due to low grain yield and protein ratios. Çatalyazı and Çağlayan genotypes in irrigated condition and all einkorn and emmer genotypes in rain-fed agriculture condition were superior to Kirik cultivar in terms of grain yield. The genotypes of the einkorn had a significantly higher grain protein content compared to the Kirik and emmer genotypes, which had similar protein content. It is possible to state that Çatalyazı and Çağlayan genotypes are more promising than Kırik cultivar to get more economical summer cereal production in Erzurum region. The applicability of winter planting, optimum seeding rate and nitrogen dose may be useful for achieving higher yields in these genotypes. The most important problem regarding these genotypes is the high risk of lodging. Considering their high adaptability to poor soils, the einkorn and emmer genotypes that are appropriately chosen have the potential to be important alternative for farmers in summer planting under low input farming and organic farming conditions.

\section{Acknowledgements}

This research was supported by “The Atatürk University, Scientific Research Projects Commission” (Project number: FBA2017-6188).

\section{References}

Altan A, Yağcı S, Maskan M \& Göğüş F (2006). Evaluation of barley products. $9^{\text {th }}$ Turkey Food Congress, 24-26 May 2006, Bolu s. 495-498 (in Turkish)

American Association of Cereal Chemist (2010). Approved methods of the AACC. St. Paul, MN, USA

Aslan D, Ordu B \& Zencirci N (2016 a). Einkorn wheat (Triticum monococcum ssp. monococcum) tolerates cold stress better than bread wheat (Triticum aestivum L.) during germination. Journal of Central Research Institute for Field Crops 25(2): 182-192 https://doi.org/10.1016/j.jcs.2021.103177

Aslan D Zencirci N, Etöz M, Ordu B \& Bataw S (2016 b). Bread wheat responds salt stress better than einkorn wheat does during germination. Turk J Agric For 40: 783-794 https://doi.org/10.3906/tar-1604-59 
Balouchi H R, Sarvestani Z T \& Sanavy S A M M (2005). Agronomic factors on selected hulles barley genotypes. Journal of Agronomy 4(4): 333-339

Bogale A \& Tesfaye K (2011). Relationships between kernel ash content, water use efficiency and yield in durum wheat under water deficit induced at different growth stages. African J. Basic Appl. Science 3(3): 80-86

Borghi B, Castagna R, Corbellini M, Heun M \& Salamini F (1996). Breadmaking quality of einkorn wheat (Triticum monococcum ssp. monococcum). Cereal Chem 73(29): 208-214 https://doi.org/10.1016/s1161-0301(14)80038-5

Brandolini A, Hidalgo A \& Moscaritolo S (2008). Chemical composition and pasting properties of einkorn (Triticum monococcum L. ssp. monococcum) whole meal flour. Journal of Cereal Science 47: 599-609 https://doi.org/10.1016/j.jcs.2007.07.005

Chatzav M, Peleg Z, Ozturk L, Yazici A, Fahima T, Cakmak I \& Saranga Y (2010). Genetic diversity for grain nutrients in wild emmer wheat: potential for wheat improvement. Annals of Botany 105: 1211-1220 https://doi.org/10.1093/aob/mcq024

Çağlar Ö, Öztürk A \& Bulut S (2006). Adaptation of some bread wheat cultivars in Erzurum Plain conditions. Atatürk University, Journal of Agriculture Faculty 37(1): 1-7 (in Turkish with abstract in English)

Dickin E, Steele K, Edwards-Jones G \& Wright D (2012). Agronomic diversity of naked barley (Hordeum vulgare L.): A potential resource for breeding new food barley for Europe. Euphytica 184: 85-99 https://doi.org/10.1007/s10681-011-0567-y

Feng K, Cui L, Lv S, Bian J, Wang M, Song W \& Nie X (2018). Comprehensive evaluating of wild and cultivated emmer wheat (Triticum turgidum L.) genotypes response to salt stress. Plant Growth Regul 84: 261-273 https://doi.org/10.1007/s10725-017-0337-5

Frederick J R \& Camberato J J (1995). Water and nitrogen effects on winter in the Southeastern Coastal Plain: II. Physiological respons. Agronomy Journal 87: 521-526 https://doi.org/10.2134/agronj1995.00021962008700030021x

Geisslitza S, Wieser H, Scherfa K.A \& Koehler P (2018). Gluten protein composition and aggregation properties as predictors for bread volume of common wheat, spelt, durum wheat, emmer and einkorn. Journal of Cereal Science 74: 19-27 https://doi.org/10.1016/j.jcs.2018.08.012

Gomez-Macpherson H \& Richards R A (1995). Effects of sowing time on yield and agronomic characteristics of wheat in south-eastern Australia. Aust J. Agric. Research 46(7): 1381-1399 https://doi.org/10.1071/ar9951381

Guarda G, Padovan S \& Delogu G (2004). Grain yield, nitrogen-use efficiency and baking quality of old and modern Italian bread-wheat cultivars grown at different nitrogen levels. European Journal of Agronomy 21(2): 181-192 https://doi.org/10.1016/j.eja.2003.08.001

Hafsi M, Mechmeche W, Bouamama L, Djekoune A, Zaharieva M \& Monneveux P (2000). Flag leaf senescence, as evaluated by numerical image analysis, and its relationship with yield under drought in durum wheat. Journal of Agronomy and Crop Science 185(4): 275-280 https://doi.org/10.1046/j.1439-037x.2000.00436.x

Helm C V \& Francisco A D (2004). Chemical characterization of brazilian hulless barley varieties, flour fractionation, and protein concentration. Sci. Agric. (Piracicaba, Braz.) Nov./Dec 61(6): 593-597 https://doi.org/10.1590/s0103-90162004000600005

Jaradat A A (2011). Ecogeography, genetic diversity, and breeding value of wild emmer wheat (Triticum dicoccoides). AJCS 5(9): 1072-1086

Kaplan M, Akar T, Kamalak A \& Bulut S (2014). Use of diploid and tetraploid hulled wheat genotypes for animal feeding. Turk J Agric For 38: 838-846 https://doi.org/10.3906/tar-1401-20

Karagöz A \& Zencirci N (2005). Variation in wheat (Triticum spp.) landraces from different altitudes of three regions of Turkey. Genetic Resources and Crop Evolution 52: 775-785 https://doi.org/10.1007/s10722-004-3556-3

Karimi M M \&Siddique K H M (1991). Crop growth and relative growth rates of old and modern wheat cultivars. Australian Journal of Agricultural Research 42(1): 13-20 https://doi.org/10.1071/ar9910013

Kinner M, Nitschko S, Sommeregger J, Petrasch A, Linsberger-Martin, G, Grausgruber H, Berghofer E \& Siebenhandl-Ehn S (2011). Naked barley optimized recipe for pure barley bread with sufficient beta-glucan according to the EFSA health claims. Journal of Cereal Science 53: 225-230 https://doi.org/10.1016/j.jcs.2011.01.001

Konvalina P, Capouchova I, Stehno Z \& Moudry J (2010). Agronomic characteristics of the spring forms of the wheat landraces (einkorn, emmer, spelt, intermediate bread wheat) grown in organic farming. J. Agrobiol 27(1): 9-17 https://doi.org/10.2478/s10146-009-0002-3

Konvalina P, Capouchova I \& Stehno Z (2012). Agronomically important traits of emmer wheat. Plant Soil Environ 58(8): 341-346 https://doi.org/10.17221/174/2011-pse

Konvalina P, Capouchová I \& Stehno Z (2013). Baking quality of hulled wheat species in organic farming. Nutrition and Food Engineering 7(6): 370-373 https://doi.org/10.5772/29330

Köten M, Ünsal A S \& Atlı A (2013). Evaluation of barley as human food. Turkish Journal of Agriculture-Food Science and Technology 1(2): 51-55 (in Turkish with abstract in English) https://doi.org/10.24925/turjaf.v1i2.51-55.25

Kucek L K, Dyck E, Russell J, Clark L, Hamelman J, Burns-Leader S, Senders S, Jones J, Benscher D, Davis M, Roth G, Zwinger S, Sorrells M E \& Dawson J C (2017). Evaluation of wheat and emmer varieties for artisanal baking, pasta making, and sensory quality. Journal of Cereal Science 74: 19-27 https://doi.org/10.1016/j.jcs.2016.12.010

Lachman J, Orsak M, Pivec V \& Jiru K (2012 a). Antioxidant activity of grain of einkorn (Triticum monococcum L.), emmer (Triticum dicoccum Schuebl [Schrank]) and spring wheat (Triticum aestivum L.) varieties. Plant Soil Environ 58(1): 15-21 https://doi.org/10.17221/300/2011-pse

Lachman J, Musilova J, Kotikova Z, Hejtmankova K, Orsak M \& Pribyl J (2012 b). Spring, einkorn and emmer wheat species - potential rich sources of free ferulic acid and other phenolic compounds. Plant Soil Environ 58(8): 347-353 https://doi.org/10.17221/289/2012-pse

Longin C F H \& Würschum T (2016). Back to the future - Tapping into ancient grains for food diversity. Trend Plant Science 21: 731-737 https://doi.org/10.1016/j.tplants.2016.05.005

Morgounov A, Keser M, Kan M, Küçükçongar M, Özdemir F, Gummadov N, Muminjanov H, Zuev E \& Qualset C O (2016). Wheat landraces currently grown in Turkey: distribution, diversity, and use. Crop Science 56: 3112-3124 https://doi.org/10.2135/cropsci2016.03.0192

Ottekin A, Akar T, Tosun H, Ozan A N \& Demir Z (1996). Determination of agronomic and quality characteristics of hulless barley. $4^{\text {th }}$ National Nuclear Agriculture and Livestock Congress, 25-27 September 1996, Bursa pp.103-108 (in Turkish with abstract in English)

Öztürk A (1999a). Drought resistance in bread wheat genotypes. Turk J. Agric. For. 23 (supplement issue 5): 1237-1247 (in Turkish with abstract in English)

Öztürk A (1999b). The effect of drought on the growth and yield of winter wheat. Turk J. Agric. For. 23(5): 531-540 (in Turkish with abstract in English)

Öztürk A, Çağlar Ö \& Tufan (2001). Adaptation of some barley cultivars in Erzurum condition. Atatürk University, Journal of Agriculture Faculty 32(2): 109-115 (in Turkish with abstract in English)

Öztürk A \& Aydın F (2004). Effect of water stress at various growth stages on some quality characteristics of winter wheat. Journal of Agronomy and Crop Science 190(2): 93-99 https://doi.org/10.1046/j.1439-037x.2003.00080.x 
Öztürk A, Çağlar Ö \& Bulut S (2006). Growth and yield response of facultative wheat to winter sowing, freezing sowing and spring sowing at different seeding rates. J. Agronomy \& Crop Science 192: 10-16 https://doi.org/10.1111/j.1439-037x.2006.00187.x

Panozzo J F \& Eagles H A (2000). Cultivar and environmental effects on quality characters in wheat. II. Protein. Aust. J. Agric. Research 51: 629-636 https://doi.org/10.1071/ar99137

Salantur A, Öztürk A, Akten Ş, Şahin F \& Dönmez M F (2006). Growth and yield response of spring wheat Triticum aestivum L to inoculation with rhizobacteria. Plant Soil Environ 3: 111-118 https://doi.org/10.17221/3354-pse

Sterna V, Zute S, Jansone I \& Kantane I (2017). Chemical composition of covered and naked spring barley varieties and their potential for food production. Pol. J. Food Nutr. Science 67(2): 151-158 https://doi.org/10.1515/pjfns-2016-0019

Taketa S, Kikuchi S, Awayama T, Yamamoto S, Ichii M \& Kawasaki S (2004). Monophyletic origin of naked barley inferred from molecular analyses of a marker closely linked to the naked caryopsis gene (nud). Theor Appl Genet 108: 1236-1242 https://doi.org/10.1007/s00122003-1560-1

Tobiasz-Salach R, Jankowska D, Bobrecka-Jamro D \& Buczek J (2012). Grain yield and chemical composition of new, naked lines of barley grown in conditions of subcarpathian region. Acta Sci. Pol., Agricultura 11(1): 99-111 https://doi.org/10.2478/v10081-009-0004-2

Troccoli A \& Codianni P (2005). Appropriate seeding rate for einkorn, emmer, and spelt grown under rainfed condition in southern Italy. Europ J Agron 22: 293-300 https://doi.org/10.1016/j.eja.2004.04.003

Wiegand C L \& Cuellar J A (1981). Duration of grain filling and kernel weight of wheat as affected by temperature 1. Crop Science 21(1): 95101 https://doi.org/10.2135/cropsci1981.0011183x001100010027x

Yan W, Yao H, Nie S \& Li Y (2016). Mineral analysis of hulless barley grown in different areas and its $\beta$-glucan concentrates. Cogent Food and Agriculture 2: 1-8 https://doi.org/10.1080/23311932.2016.1186139

Zaharieva M \& Monneveux P (2014). Cultivated einkorn wheat (Triticum monococcum L. ssp. monococcum): the long life of a founder crop of agriculture. Genet Resour Crop Evol 61:677-706 https://doi.org/10.1007/s10722-014-0084-7

Zeng X Q (2015). Genetic variability in agronomic traits of a germplasm collection of hulless barley. Genetics and Molecular Research 14(4): 18356-18369 https://doi.org/10.4238/2015.december.23.23

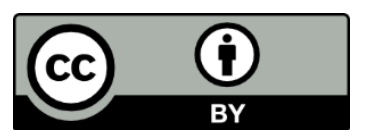

C 2021 by the authors. Licensee Ankara University, Faculty of Agriculture, Ankara, Turkey. This article is an open access article distributed under the terms and conditions of the Creative Commons Attribution (CC BY) license (http://creativecommons.org/licenses/by/4.0/). 